\title{
Nature, nurture and psychodarwinism
}

SIR - Part of the danger to which John Maddox draws attention in his remarks about genetic triumphalism ${ }^{1}$ may be a result of lingering behaviourism - a school of thought distinguished by its emphasis on nurture (which it called 'conditioning') and its tendency to ignore evolution. As my colleague Helena Cronin has recently pointed out, Darwin's own approach to explaining human behaviour was 'psychological' rather than 'ethological' or 'sociological' because Darwin was "interested in our emotions rather than our actions" 2 . A prime example was Darwin's view of "the coming of the sense of pleasure and pain as one of the most important steps in the development of mind"3. As David Barash has pointed out, what Darwin anticipates here is what Freud was later to call "the pleasure-unpleasure principle" - a psychological mechanism that demonstrably evolved to promote behaviour normally advantageous to the survival and reproductive success of the organism's genes and to discourage the converse 4 .

What Maddox calls the strong genetic principle is often suggested by a way of reporting scientific findings that links genes with measured behaviour without mention of the mind that mediates the two. But specifying nurture as another influence on behaviour does not remedy this neglect. On the contrary, it encourages a view of nurture as antithetical to nature without limiting the excess to which both sides can be driven in their dispute about which can best explain behaviour. By contrast, the pleasure-as-acarrot-and-pain-as-a-stick model of genetic influence necessarily implies a decision-making agency that can be influenced by it. Our subjective experience of conflicts occasioned by the pleasure principle should remind us that we have choices to make and that those choices need not always serve it. If we add to this picture the influence of nurture on our conscience and nature on our appetites we arrive at a model of the mind that is an effective reply to both genetic and cultural triumphalism. As Darwin anticipated, the issue of how genes influence behaviour is ultimately neither a genetic nor sociological issue, but a psychological one.

\section{Christopher Badcock}

Department of Sociology,

London School of Economics,

Houghton Street,

London WC2A 2AE, UK

SIR - Maddox ${ }^{1}$ draws attention to "the growing belief in a kind of genetic predestination". He says the lessons of 40 years of molecular biology may have "sunk in too well", creating in the public consciousness an oversimplified view of the genes as biological programs determining every aspect of life.

Few scientists will disagree that nurture is of importance in developing a phenotype. It is, indeed, a subject thoroughly treated by undergraduate textbooks. Considering the limited possibilities for correlating a human phenotype with a specific genotype, "genetic predestination", meaning anything more than tenable statistical significance, is mere belief. However, this - in historical terms dubious belief is not due solely to misleading popular science or "too zealous scientific advocacy of the importance of human genome studies".

It is a daily encountered fact that "life science" to a large extent has turned into "life technology". The advantage of this development is obvious. Vast economic resources in combination with scientific understanding of diseases has provided society with an efficient and widespread health-care system. But the chimaera of science and technology doesn't necessarily have the head of science and the forceful body of commercialism. Such curious signs, as pointed out in your article, of scientific research replacing prudence in interpreting results with "triumphalism", should be a warning. Genetic predestination has a tempting simplicity, appealing to those who are guided by another motive than that of understanding nature.

Despite the difficulties in interpreting genetic information, I fear that genetic predestination as a chosen model could have a renaissance in areas of commercial exploitation of genetic science. Attempts to re-establish the role of nurture by scientific discussion would do little to change this situation. A much broader debate on the interpretation of genetic information, concerning both scientific principles as such and their translation into a commercial context, is needed.

\section{Thomas Vorup Jensen}

Institute for Medical Microbiology, Bartholin Building,

Aarhus University,

8000 Århus C, Denmark

SIR - It is sad to see Maddox ${ }^{1}$ treat psychology with a cavalier disregard for empirical support that he would not dream of in relation to physics or molecular biology. He dismisses the discussions of the $1960 \mathrm{~s}$ about the inheritance of IQ as though the arguments in favour of a strong genetic influence upon individual differences in intelligence had since been shown to be false. In fact, there is now general acceptance among serious workers in this field that those arguments were essentially correct $^{5-8}$. To make matters worse, he then lumps together "a century of psychol- ogy and psychoanalysis" as though these two disciplines had an equivalent empirical status. Would he do the same for astronomy and astrology?

\section{J. A. Gray}

Department of Psychology,

Institute of Psychiatry,

De Crespigny Park,

Denmark Hill, London SE5 3AF, UK

1. Maddox, J. Nature 366, 107 (1993).

2. Cronin, H. The Ant \& the Peacock: Altruism \& Sexual Selection from Danwin to Today (Cambridge University Press, 1991).

3. Badcock. C. PsychoDarwinism: The New Synthesis of Darwin and Freud (Harper-Collins, London, in the press) 4. Barash, D. Sociobiology: The Whisperings Within (Souvenir, London, 1979)

5. Bouchard, T. J. in Biological Approaches to the Study of Human Intelligence (ed. Vernon, P. A.) 33-94. (Ablex, Norwood, New Jersey, 1993).

6. Loehlin, J. C. Am. Psychol. 44, 1285-1292 (1989)

7. Horn, J. M. Loehlin, J. C. \& Willerman, L. Behav. Genet. 12 479-516(1982)

8. Vernon, P. E. (ed.) Biological Approaches to the Study of Human intelligence. (Ablex, Norwood, New Jersey, 1993).

\section{Helping Russia}

SIR - Your readers should know of the benefits to Russian science of the operation of the International Science Foundation (ISF), known in the former Soviet Union as the Soros Foundation.

I am one of more than 25,000 scientists supported by the first wave of ISF activity in the form of emergency $\$ 500$ grants. I have seen how stimulating it was, both financially and psychologically. It is valuable to know that the international scientific community is concerned about the fate of Russian science.

With redoubled energy and optimism, many scientists were involved in the second step - preparation of proposals for large, scientific projects in competition for large grants over the next three years. And, again, what is very important is not only the financial support but also gaining it through grant competition, which is new and almost unprecedented for us. The competition is based on the international peer review system, and that will introduce international scientific criteria to our science.

Of no less importance is the support of our scientific libraries, which have become empty over the past few years, and support for international travelling by our scientists.

The ISF's activities are producing revolutionary changes in all aspects of our scientific life. I am most grateful to $\mathrm{Mr}$ George Soros for his most fruitful and wise programme.

Natalia Engelhardt

Russian Centre for Oncology,

Moscow, Russia

Letters submitted for Correspondence should be typed, double-spaced, on one side of the paper only. 